\title{
Biocompatible l-carrageenan- $\gamma$-maghemite nanocomposite for biomedical applications - synthesis, characterization and in vitro anticancer efficacy
}

\author{
Maya Raman ${ }^{\dagger}$, Viswambari Devi ${ }^{\dagger}$ and Mukesh Doble
}

\begin{abstract}
Background: Carrageenans are naturally occurring hydrophilic, polyanionic polysaccharide bioploymers with wide application in pharmaceutical industries for controlled drug delivery. Magnetic nanoparticles with their exceptional properties enable them to be an ideal candidate for the production of functional nanostructures, thus facilitating them for biomedical applications. The development of novel nanocomposite by coupling the synergistic effects of the sulfated polysaccharide (iota carrageenan) and a magnetic nanoparticle (maghemite) may offer new interesting applications in drug delivery and cancer therapy. The nanocomposite was characterized by ultraviolet-visible spectroscopy, high resolution scanning electron microscopy, dynamic light scattering analysis, Fourier transform infrared spectroscopy and powder XRD to highlight the possible interaction between the two components. Biocompatibility and the anticancer efficacy of the nanocomposite were assayed and analysed in vitro.
\end{abstract}

Results: Results suggested that iota carrageenans have electrostatically entrapped the maghemite nanoparticles in their sulfate groups. Biocompatibility of the nanocomposite (at different concentrations) against normal cell lines (HEK-293 and L6) was confirmed by MTT assay. Hoechst 33342 and 7-AAD staining studies under fluorescent microscopy revealed that the nanocomposite is able to induce appoptosis as the mode of cell death in human colon cancer cell line (HCT116). Cell apoptosis here is induced by following the ROS-mediated mitochondrial pathway, combined with downregulation of the expression levels of mRNA of XIAP and PARP-1 and upregulation of caspase3, BCl-2 and BCl-xL.

Conclusions: This novel nanocomposite is biocompatible with potential properties to serve in magnet aided targeted drug delivery and cancer therapy.

Keywords: I-carrageenan, y-maghemite nanoparticles, Nanocomposite, Biocompatible, Apoptosis, Drug delivery, Hyperthermia

\section{Introduction}

The advancements in the area of nanoparticles and nanotechnology have offered an understanding and management of the materials at atomic and molecular levels. It has also assisted in fabricating advanced materials with added magnetic, electrical, optical and

\footnotetext{
* Correspondence: mukeshd@iitm.ac.in

${ }^{\dagger}$ Equal contributors

Bioengineering and Drug design Lab, Department of Biotechnology,
} IIT-Madras, Chennai 600036, India biological properties for pharmaceutical and biomedical applications [1]. Nanovectors in the field of delivery are promising novel tools for controlled release of drugs. In recent years, the unique novel properties (superparamagnetism, high coercivity, low Curie temperature and high magnetic susceptibility) of iron oxide nanoparticles (magnetite, maghemite) have been exploited to make it inevitable in magnetic resonance imaging (MRI), magnetic fluid hyperthermia, controlled drug delivery systems and cancer therapy [2]. Nevertheless, these magnetic nanoparticles

\section{Ciomed Central}

(C) 2015 Raman et al.; licensee BioMed Central. This is an Open Access article distributed under the terms of the Creative Commons Attribution License (http://creativecommons.org/licenses/by/4.0), which permits unrestricted use, distribution, and reproduction in any medium, provided the original work is properly credited. The Creative Commons Public Domain Dedication waiver (http://creativecommons.org/publicdomain/zero/1.0/) applies to the data made available in this article unless otherwise stated. 
are functionally efficient to perform these tasks only when incorporated with suitable polymer $[3,4]$. Encapsulating magnetic nanoparticles within a polymer not only stabilizes the nanoparticles but also provides various chemical functionalizations. Many polysaccharide-based magnetic nanocomposites such as, magnetite $\left(\mathrm{Fe}_{3} \mathrm{O}_{4}\right)$-dextran, $\mathrm{Fe}_{3} \mathrm{O}_{4}$-chitosan, $\mathrm{Fe}_{3} \mathrm{O}_{4}$-alginate, $\mathrm{Fe}_{3} \mathrm{O}_{4}$-heparin, $\mathrm{Fe}_{3} \mathrm{O}_{4}$ pullulan acetate, $\mathrm{Fe}_{3} \mathrm{O}_{4}$-starch, $\mathrm{Fe}_{3} \mathrm{O}_{4}$-k-carrageenan, maghemite $\left(\gamma-\mathrm{Fe}_{2} \mathrm{O}_{3}\right)$-dextan/sucrose, were successfully used in bioseparation and purification [5,6], bioassays and sensors [7-9], biolabelling and imaging [10,11], cancer hyperthermia [12,13], cardiovascular therapies [14] and drug delivery $[15,16]$.

Carrageenans are naturally occurring high molecular weight, hydrophilic polysaccharides extracted from red sea weeds of phylum Rhodophyta. These are polyanionic linear sulfated galactans with a sequence of D-galactopyranose and 3,6-anhydrogalactopyranose residues bonded by alternating $\alpha(1 \rightarrow 3)$ and $\beta(1 \rightarrow 4)$ linkages [17]. Based on the number and position of ester sulfate groups $\left(-\mathrm{SO}_{3}^{-}\right)$on the galactose units, these are classified into kappa ( $\mathrm{k}$ ) -, iota $(\mathrm{l})$-, and lambda $(\lambda)$ - carrageenan (main commercial variants). $\mathrm{l}$-Carrageenan ( $\mathrm{l}-\mathrm{car}$ ) is composed of D-galactose4-sulphate (G4S) and 3, 6-anhydro-D-galactose-2-sulfate (DA2S). These biocompatible and biodegradable biomacromolecules are extensively used in food and pharmaceutical industries. In pharmaceutical industry, these play a significant role as gelling agents in controlled drug release and prolonged retention. Their anticancer, antioxidant, anticoagulant, antihyperlipid, antiviral and immunomodulatory activities have gained several pharmacological applications $[18,19]$. The $\mathrm{t}$-carrageenan has been reported to possess high metal binding activity [20]. They are reported to act as sorbents and aid in binding heavy metals including yttrium $\left(\mathrm{Y}^{3+}\right)$ and lead ions $\left(\mathrm{Pb}^{2+}\right)$ [20]. This intrinsic metal binding property of carrageenans and other polysaccharides are successfully employed in nanoparticle synthesis and encapsulation; and hence, in making nanoparticles suitable for a broad spectrum of biomedical and biotechnological applications [21].

Carneiro et al. [22] reported that $\gamma-\mathrm{Fe}_{2} \mathrm{O}_{3}$ nanoparticles coated citrate and rhodium (II) citrate enhance cytotoxicity on breast carcinoma. Degraded $ı$ - car was also reported to have antitumor activity towards human osteosarcoma cell line both in vitro and in vivo [23]. Hence, the synergic effect of the nanoparticles and the polysaccharides could be a new area of research which could confer beneficial functionalities and multiple bioapplications to the product developed. In our study, $\gamma$ - maghemite $\left(\mathrm{Fe}_{2} \mathrm{O}_{3}\right)$ nanoparticles were combined with ı - car in a significant way to develop a novel nanocomposite material. These were then characterized and subjected to in vitro studies to open up their possible range of applications in cancer research.

\section{Results and discussion}

l-car is an anionic polysaccharide with high $\zeta$ potential value. This anionic nature is because of the sulfate group in each unit of D-galactopyranose-4-sulfate and 3, 6-anhydrogalactose units. The $\zeta$-potential of I-car was $-52.84 \pm 3.6 \mathrm{mV}$ and that of $\mathrm{l}$-car- $\gamma-\mathrm{Fe}_{2} \mathrm{O}_{3}$ nanocomposite was $-7.70 \pm 2.8 \mathrm{mV}$. This lowering in surface charge of the latter could be attributed to the inclusion of the positively charged $\gamma-\mathrm{Fe}_{2} \mathrm{O}_{3}$ nanoparticles $(+33 \pm 3 \mathrm{mV})$ to the surface of anionic l-car. The electrostatic attraction between anionic sulfate groups $\left(-\mathrm{SO}_{4}^{-}\right)$on the carrageenan molecule and cationic patches $\left(-\mathrm{Fe}^{2+}\right)$ on maghemite may interact and contribute to the nanocomposite size and zeta potential [24]. Similar results were reported in many studies and this change in the $\zeta$-potential could be highly dependent on the concentration of components in the composite [25,26]. SEM micrographs showed maghemite nanoparticles dispersed throughout the carrageenan microfibrils (Figure 1). However, for in vitro studies, the nanoparticle dispersed microfibrillar composite was ultrasonicated and washed in buffer to get nanometer sized particles that were larger than maghemite nanoparticles $(21 \pm 3.6 \mathrm{~nm})$ used in the preparation of the composite. The average particle size ranging from $200-550 \pm 10 \mathrm{~nm}$ was observed and this wide range of distribution may be due to their aggregation (Additional file 1).

The UV absorption maxima for I-car was observed at $296 \mathrm{~nm}$, which shifted to $304 \mathrm{~nm}$ in the nanocomposite possibly indicating structural modification in l-car, which

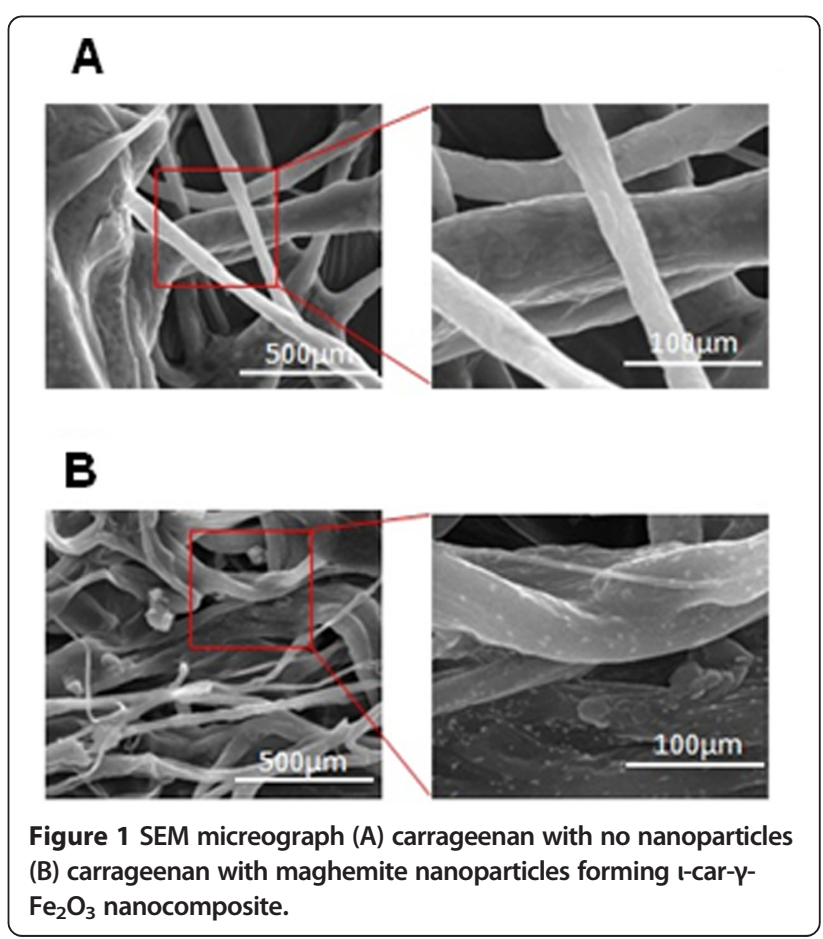


might be due to the entrapment of maghemite nanoparticles [27] (Additional file 2).

The FTIR bands specific to I-car are observed in both the samples (Figure 2, Table 1), with few exceptions in the lower fingerprint region $\left(800-400 \mathrm{~cm}^{-1}\right)$. Broad bands are observed between $3400-3000 \mathrm{~cm}^{-1}$ corresponding to the hydroxyl groups in the polysaccharide which is responsible for the hydrophilic nature of the carrageenan [28]. The bands between $2900-2700 \mathrm{~cm}^{-1}$ are assigned to the asymmetrical stretching vibrations in $-\mathrm{CH}_{2}$ of the galactose units [28]. The characteristic band in the $1210-1260 \mathrm{~cm}^{-1}$ region was attributed to the sulfate esters that were present in both, confirming the retention of the sulfation in the latter [29]. The peak at $1070 \mathrm{~cm}^{-1}$ is attributed to glycosidic linkages in the polysaccharides [29]. Presence of 3, 6-anhydro-D-galactopyranose units in both was confirmed from the presence of bands at 894 and $917 \mathrm{~cm}^{-1}$, and that of Dgalactopyranose-4-sulfate (G4S) units by the presence of bands at 848 and $846 \mathrm{~cm}^{-1}$. The band specific to $\mathrm{t}-\mathrm{car}$

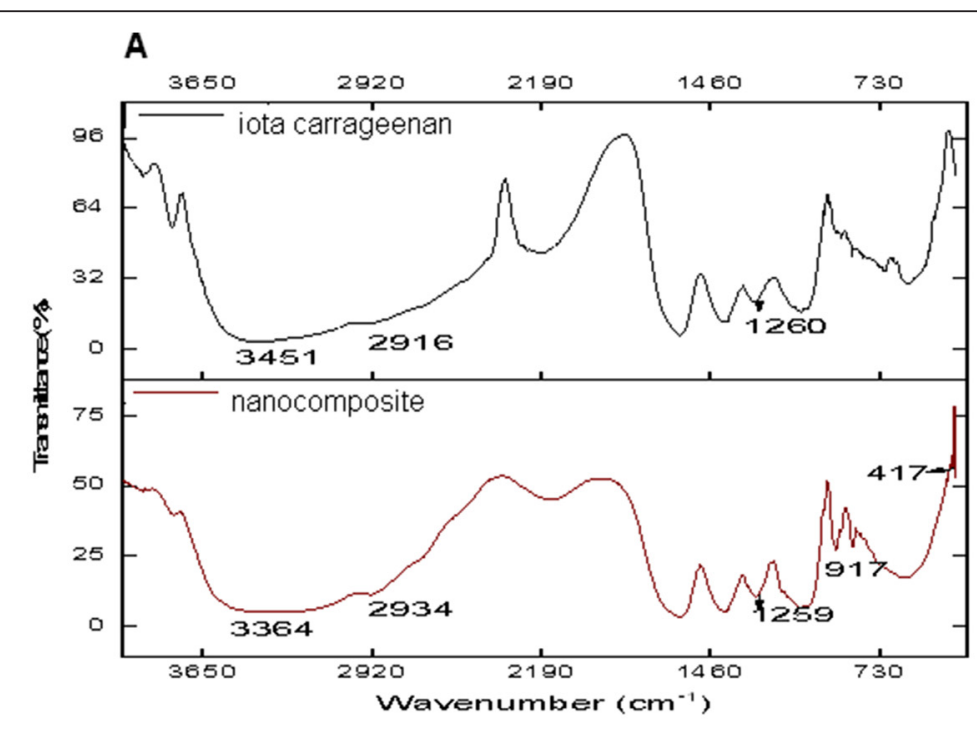

B

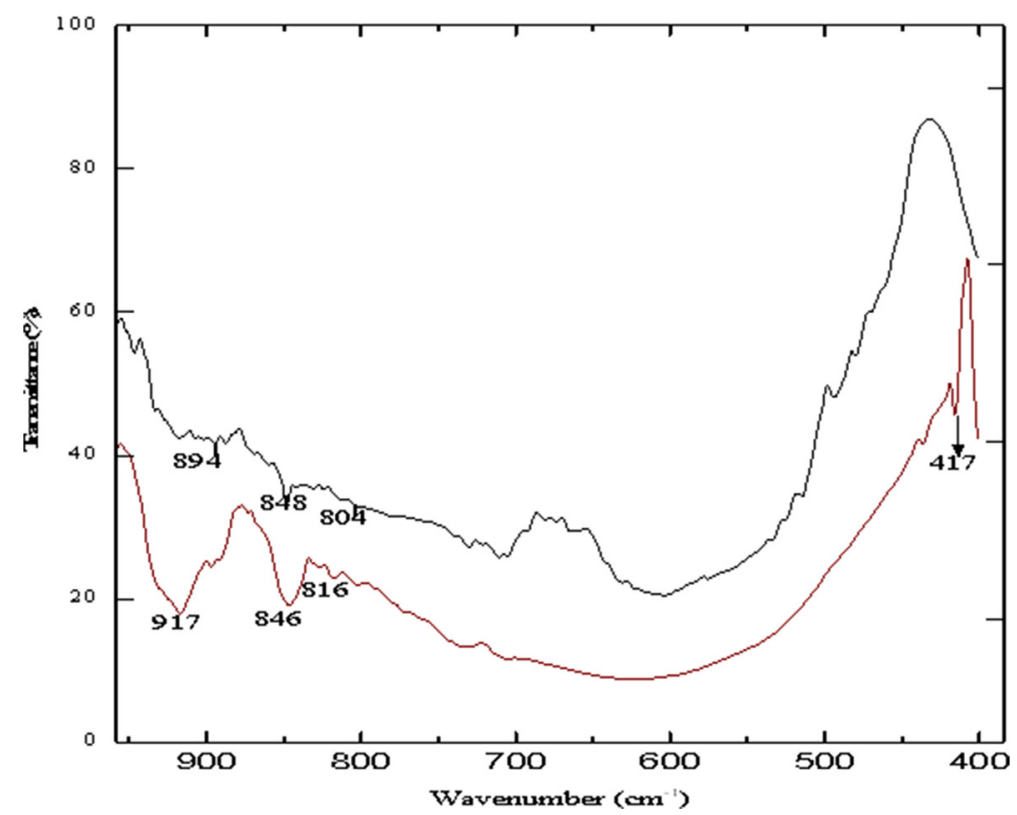

Figure 2 FTIR spectrum of (A) I-car and I-car- $-\mathrm{Fe}_{2} \mathrm{O}_{3}$ nanocomposite (B) magnified lower finger print region of FTIR spectrum of I-car and $\mathrm{t}-\mathrm{car}-\mathrm{\gamma}-\mathrm{Fe}_{2} \mathrm{O}_{3}$ nanocomposite. 
Table 1 FTIR spectrum assignments

\begin{tabular}{|c|c|c|c|}
\hline $\begin{array}{l}\text { Functional } \\
\text { groups }\end{array}$ & $\begin{array}{l}\text { Wavelength }\left(\mathrm{cm}^{-1}\right) \\
\text { of corresponding } \\
\text { functional groups (1-car) }\end{array}$ & & $\begin{array}{l}\text { l-car- } \gamma-\mathrm{Fe}_{2} \mathrm{O}_{3} \\
\text { composite }\end{array}$ \\
\hline Hydroxyl & $3000-3600$ & 3451 & -3364 \\
\hline $\mathrm{C}-\mathrm{H}$ stretch & $2900-2700$ & 2916 & -2934 \\
\hline Ester sulfate & $1220-1260$ & 1260 & -1259 \\
\hline $\begin{array}{l}3,6 \\
\text { anhydrogalactose }\end{array}$ & $928-933$ & 894- & 917 \\
\hline G4S & $840-850$ & $848-$ & 846 \\
\hline $\begin{array}{l}3,6 \\
\text { anhydrogalactose } \\
-2 \text { - sulfate }\end{array}$ & $800-805$ & 804- & 816 \\
\hline $\mathrm{Fe}-\mathrm{O}$ stretch & $500-400$ & - & 417 \\
\hline
\end{tabular}

appears at $805 \mathrm{~cm}^{-1}$, which indicates the presence of sulfate group at C2-position in the 3, 6-anhydrogalactose unit (DA2S) [30]. This band however shifts to lower wavenumbers in the spectrum of the nanocomposite. This as well as the shift observed at $917 \mathrm{~cm}^{-1}$ in the nanocomposite may be due to the interaction of maghemite nanoparticles with the sulfate ester group in the 3 , 6- anhydrogalactose-2-sulfate units. The appearance of sharp intense peak at $417 \mathrm{~cm}^{-1}$ corresponds to Fe-O stretch (Figure 2B) [31]. This could possibly be due to the impregnation of iron nanoparticles in l-car mostly by electrostatic interaction with the sulfate groups of 3,6 anhydrogalactose-2-sulfate units [27].

$\mathrm{X}$-ray powder diffraction pattern of $\mathrm{l}$-car and $\mathrm{l}-\mathrm{car}-\gamma-$ $\mathrm{Fe}_{2} \mathrm{O}_{3}$ nanocomposite indicate intense peaks at Bragg angles $(2 \theta), 28^{\circ}$ and $40^{\circ}$, while less intense peaks at $36^{\circ}$, $50^{\circ}, 11^{\circ}, 29^{\circ}, 20^{\circ}, 66^{\circ}, 17^{\circ}, 23^{\circ}, 46^{\circ}, 18^{\circ}, 41^{\circ}, 45^{\circ}$ and $58^{\circ}$. $\gamma-\mathrm{Fe}_{2} \mathrm{O}_{3}$ nanoparticles have intense peaks at $35^{\circ}, 63^{\circ}, 57^{\circ}$ and $30^{\circ}$. The XRD-diffractogram of the nanocomposite have the two intense peaks for 1 -car $\left(28^{\circ}\right.$ and $\left.40^{\circ}\right)$ and two peaks specific for $\gamma-\mathrm{Fe}_{2} \mathrm{O}_{3}$ nanoparticles $\left(66^{\circ}\right.$ and $58^{\circ}$ ) and other characteristic peaks of its own at $14^{\circ}, 25^{\circ}$ and $26^{\circ}$ (Figure 3, Table 2) [32,33]. Diffraction studies by Millane et al. [32], Janaswamy and Chandrasekaran [33] have shown that t-car has a double helical structure with sulfate protruding away from the centre of helix. It has a trigonal lattice arrangement with small changes in the unit cell dimensions when it interacts with the nanoparticles.

Cell proliferation assay for t-car $(1000 \mu \mathrm{g} / \mathrm{ml})$ using 3[4, 5-dimethythiazol-2-yl]-3, 5-diphenyltetrazolium bromide dye showed, $75.4 \%$ viability of HCT116 cells and no cytotoxicity in HEK and L6 (more than 90\% of viable cells). Supportingly, Arrifin et al. [34], have observed that iota carrageenan was non-cytotoxic to normal and cancer intestinal and liver cell lines even at $2000 \mu \mathrm{g} / \mathrm{ml}$. MTT assay with $\gamma-\mathrm{Fe}_{2} \mathrm{O}_{3}$ showed that the nanoparticles were cytotoxic to HEK, L6 and HCT116 cell lines at $50 \mu \mathrm{g} / \mathrm{ml}$ and above (Additional file 3). This agrees with the studies of Prodan et al. [35], which have demonstrated that $\gamma$ $\mathrm{Fe}_{2} \mathrm{O}_{3}$ nanoparticles upto $30 \mu \mathrm{g} / \mathrm{ml}$ concentration are non-cytotoxic on HeLa cells. The $\mathrm{t}-\mathrm{car}-\gamma-\mathrm{Fe}_{2} \mathrm{O}_{3}$ nanocomposite treatment induced dose-dependent death of HCT116 cells (reduction of cell viability from 98.8 to $68.4 \%$ with an increase in the concentration from 50-500 $\mu \mathrm{g} /$ $\mathrm{mL}$, in 24 hours $(\mathrm{p}<0.01))$. The nanocomposite had no effects on the viability of HEK293 and L6 cell lines even at the highest concentrations tested (Figure 4). The concentrations of $\mathrm{l}$-car $(700 \mu \mathrm{g} / \mathrm{ml})$ and $\gamma-\mathrm{Fe}_{2} \mathrm{O}_{3}(4 \mu \mathrm{g} / \mathrm{ml})$ in nanocomposite, when used independently had no effects on the viability of HEK293 and L6 cell lines and hence were biocompatible.

Nanocomposites comprising of maghemite have been recognized for their anticancer properties [36,37] and Icar- $\gamma-\mathrm{Fe}_{2} \mathrm{O}_{3}$ nanocomposite is a novel compound that could be a potent inducer of apoptosis in various cancer cell lines. This could activate the extrinsic or intrinsic apoptotic pathways by altering the expression of apoptosis-associated or signaling proteins, cell cycle regulatory proteins and transcription factors. However, the molecular and cellular mechanism underlying these effects in HCT116 has not yet been investigated till date.

The morphological changes in the HCT116 cells and its nucleus, induced by apoptosis were examined with different dyes. Apoptotic bodies (apoptosomes) were observed with Hoechst 33342 staining in nanocompositetreated cells, but not in the control. These changes might include chromatin condensation, membrane blebbing and cell shrinkage. 7-AAD staining indicates compromised cellular membrane (late apoptotic and necrotic cells), while live cells with intact cell membranes remained dark (Figure 5A-C). Necrotic cell death might not be significant [38]. Figure 5 (D, E) shows the results of nanocomposite treated cells stained with acridine orange and ethidium bromide for $24 \mathrm{~h}$. Number of viable cells here had decreased significantly. Apoptotic cells appear bright green or reddish with fragmented nuclei. The decrease in green fluorescence observed in treated cells when compared to control could be due to the reduction in the accessibility of nucleic acid by AO or reduced overall amount of DNA in the cells which undergo apoptosis. Cells which undergo apoptosis are permeable and, hence show increased fluorescence with EB. Nanocomposite-treated cells showed a significant reduction in the cell numbers and about $82 \%$ of cells were either orange or bright green apoptotic cells (apoptosomes) with fragmented and condensed nuclei $[39,40]$. In the control, the cells were healthy with no fragmented nuclei.

Annexin-V/PI double-staining and flow cytometry revealed that the nanocomposite effectively induced apoptosis in HCT-116 cells. The proportion of apoptotic cells 
A

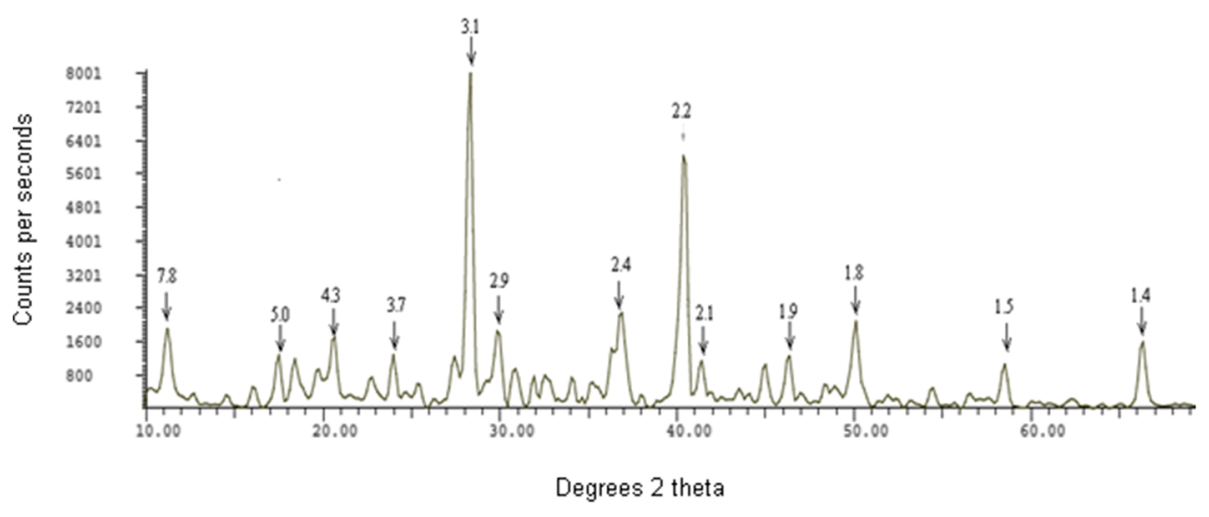

B

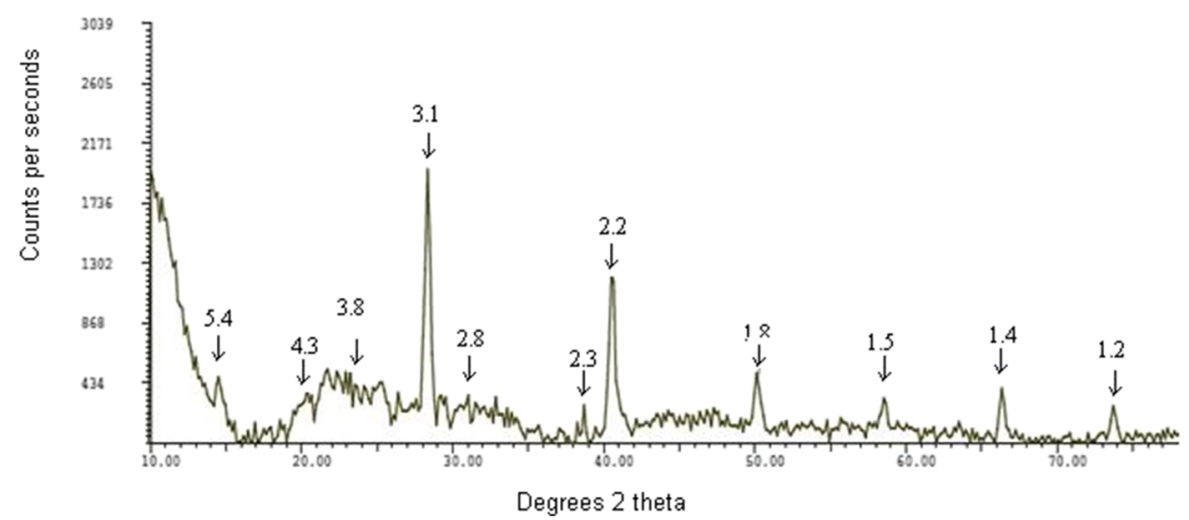

Figure 3 Powder XRD diffractogram of (A) I-car and (B) I-car- $--\mathrm{Fe}_{2} \mathrm{O}_{3}$ nanocomposite.

(lower right quadrant) increased from $15.62 \%$ in untreated cells to $16.3 \%$ in nanocomposite-treated cells in 24 hours (Figure 6A). Compared to the ROS in the control, it is found that $1 \mathrm{mM}$ of ascorbic acid markedly reduced the ROS level $(59.7 \pm 4.6 \%$ of control) in HCT116 cell lines. However, pre-incubation with $\mathrm{l}-\mathrm{car}-\gamma-\mathrm{Fe}_{2} \mathrm{O}_{3}$ nanocomposite $(500 \mu \mathrm{g} / \mathrm{ml})$ increased the ROS levels significantly $(80.8 \pm 0.4 \%$ of control, $\mathrm{p}<0.01)$.

ROS are the byproducts of normal cellular oxidative process and are involved in the initiation of apoptotic and inflammation signaling. Increased ROS levels induce depolarization of the mitochondrial membrane which produces an increased level of pro-apoptotic molecules in the cells [41]. Oxidative stress indicates the imbalance between pro-oxidants and anti-oxidants and this is controlled by multiple factors, of which imbalances caused by cellular damage is a critical one. ROS play a key role in oxidative stress, and are generated as a by-product of cellular metabolism, primarily in the mitochondria [42]. The accumulation of ROS may lead to various forms of reversible and irreversible oxidative modifications to the cellular proteins, lipids and DNA, thus, accounting for cellular damage [43]. Depending on the extent of oxidative stress, elevated levels of ROS can induce proliferation, growth arrest, senescence and apoptosis [44].

In order to evaluate the effect of $\mathrm{I}-\mathrm{car}-\gamma-\mathrm{Fe}_{2} \mathrm{O}_{3}$ nanocomposite on the increase in the hypodiploid cell proportion, a cell cycle analysis was performed. Figure $6 \mathrm{~B}$ shows slight percentage increase in the number of cells in the G2/M phase and decrease in the S-phase with respect to the control. Percentage difference in the G0phase between the two is not statistically significant. This defective G2/M phase in the nanocomposite treated cells indicate that the entry of the cells into mitosis is checked due to the DNA damage and hence, the cells undergo apoptosis [45]. Cyclin regulatory proteins and p53 pathway may have a significant role in the apoptosis [46]. Nanocomposite is observed to induce accumulation of cells in G1/S phase. Similar results are reported by Haneji et al. for fucoidan-induced cell death [47]. They also reported G1 arrest in human cancer cell, HCT116. l-car- $\gamma-\mathrm{Fe}_{2} \mathrm{O}_{3}$ nanocomposite leads to the downregulation 
Table 2 Peak intensities of (A) I-car and (B) I-car- $\gamma-\mathrm{Fe}_{2} \mathrm{O}_{3}$ composite from PXRD diffractogram

\begin{tabular}{llllll}
\hline $\begin{array}{l}\text { (A) PXRD diffractogram } \\
\text { of I-car }\end{array}$ & \multicolumn{5}{c}{$\begin{array}{l}\text { (B) PXRD diffractogram of } \\
\text { I-car- } \boldsymbol{\gamma} \text { - } \text { Fe }_{\mathbf{2}} \mathbf{O}_{3} \text { composite }\end{array}$} \\
\hline $2 \theta$ & d spacing $\left(\mathrm{A}^{\circ}\right)$ & $1 / 100$ & $2 \theta$ & $\mathrm{d}$ spacing $\left(\mathrm{A}^{\circ}\right)$ & $\mathrm{I} / 100$ \\
11.202 & 7.8924 & 24 & 14.507 & 6.1008 & 10 \\
17.512 & 5.0602 & 16 & 20.517 & 4.3254 & 6 \\
18.414 & 4.8144 & 14 & 23.221 & 3.8274 & 12 \\
20.517 & 4.3253 & 20 & 28.33 & 3.1478 & 45 \\
23.973 & 3.7091 & 16 & 31.034 & 2.8794 & 7 \\
28.33 & 3.1478 & 100 & 32.837 & 2.7253 & 7 \\
29.832 & 2.9926 & 23 & 38.696 & 2.325 & 6 \\
36.743 & 2.444 & 27 & 40.499 & 2.2256 & 28 \\
40.349 & 2.2335 & 75 & 50.265 & 1.8137 & 9 \\
41.401 & 2.1792 & 14 & 58.528 & 1.5758 & 7 \\
45.007 & 2.0126 & 13 & 66.341 & 1.4079 & 8 \\
46.359 & 1.957 & 16 & 73.703 & 1.2844 & 6 \\
50.115 & 1.8188 & 25 & & & \\
58.528 & 1.5758 & 13 & & & \\
66.341 & 1.4079 & 19 & & & \\
73.553 & 1.2866 & 11 & & & \\
\hline
\end{tabular}

of the expression levels of mRNA of XIAP and PARP-1 and upregulation of caspase-3 [48]. Of the members of the IAP protein family, XIAP, has been reported to exert the strongest anti-apoptotic function, as it inhibits caspase- 3 indicating that apoptosis is through the mitochondrial pathway [49]. However, Bcl-2, Bcl-xL and caspase-3 are upregulated in nanocomposite treated cells when compared to the control (Figure 7). This indicates that

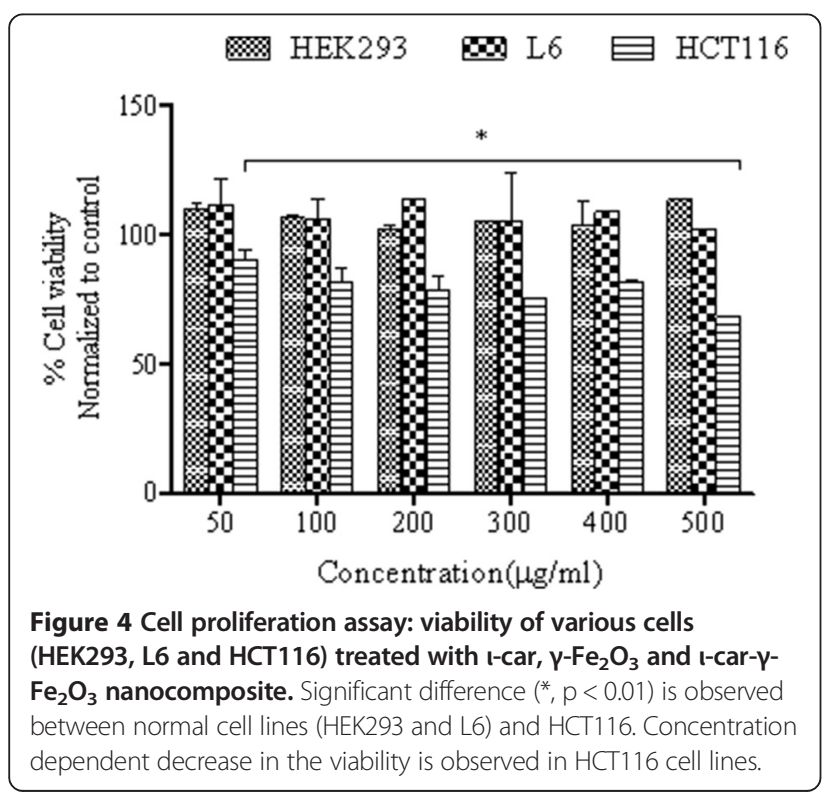

the treatment leads to mitochondrial dysfunction in HCT116 cells. PARP-1 (Poly (ADP-ribose) polymerase 1 ) is a nuclear enzyme that catalyzes the transfer of ADP-ribose polymers onto itself and other nuclear proteins in response to DNA strand break [50]. It has been widely used as a hallmark of cell apoptosis that play an important role in DNA replication and repair. Downregulation of PARP indicates the incapability of cells to respond to DNA damage and hence induces apopotic cell death [51].

Selective cleavage of 116 kD PARP between Asp214 and Gly215, to generate 89 and $24 \mathrm{kD}$ polypeptides by caspase-3 is a universal phenomenon. This is observed during programmed cell death induced by an apoptotic stimulus [52,53]. However, the Western blot of PARP from nuclear extract of the $\mathrm{l}-\mathrm{car}-\gamma-\mathrm{Fe}_{2} \mathrm{O}_{3}$ nanocomposite treated and control HCT116 cells showed same band density of uncleaved PARP (MW $116 \mathrm{kD}$ ) in the treated cells (Additional file 4). No band appeared at $50 \mathrm{kD}$ indicating that the cell death did not involve necrosis $[54,55]$. The cell death in the treated cells with un-cleavable PARP could be due to the activation of caspase-resistant PARP and the subsequent depletion of intracellular $\mathrm{NAD}^{+}$and ATP [56,53]. Apoptotic cell death due to the augmented levels of TNF- $\alpha$ and Fas were reported in fucoidan treated HL-60 cells [57]. However, it was reported that cells with PARP-null background (PARP ${ }^{-1-}$ ) exhibited a normal apoptotic response to various stimuli including TNF- $\alpha$ and anti-Fas treatment, suggesting that PARP is dispensable in the apoptotic cascade $[58,59]$. This could be understood possibly because PARP is not involved in the apoptotic cell death caused by the nanocomposite treated cells.

A20 is not significantly upregulated when compared to the control in 1 -car- $\gamma-\mathrm{Fe}_{2} \mathrm{O}_{3}$ nanocomposite treated cells. It is a nuclear factor $-\kappa \mathrm{B}(\mathrm{NF}-\mathrm{kB})$ dependent gene that shows both cell-type specific anti-apoptotic or proapoptotic functions. Changes in the mRNA expression levels of A20 could be related to both carcinogenesis and inflammatory cell signalling [48]. NF-кB (nuclear factor kappa-light-chain-enhancer of activated B cells) is a eukaryotic transcription factor that contributes equally to cell proliferation or cell death. Tumor necrosis factor- $\alpha$ induced protein 3 (tnfaip3), a gene encoding A20 protein, regulates NF- $\mathrm{kB}$ activation by interacting with various components in the upstream signaling pathway. However, both $\mathrm{A} 20$ and NF- $\mathrm{KB}$ are interrelated, since the former is an NF- $\mathrm{B}$ B dependent gene [48]. Recent reports suggest that the expression of A20 is influenced by, tumor development, immune regulation and inflammation [48]. While A20-targeted therapies may certainly add to the chemotherapeutic armamentarium, a better understanding of A20 regulation and its molecular targets and function is highly essential. Similarly, for personalized 


\section{A}

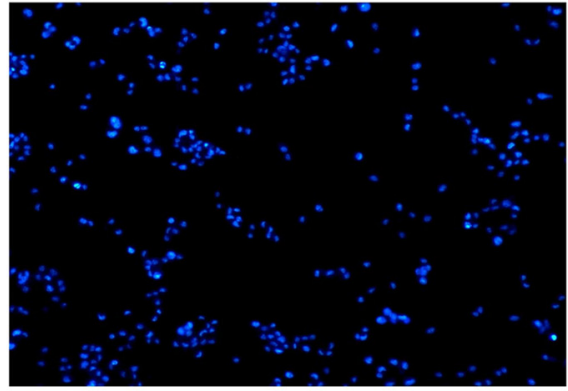

Control

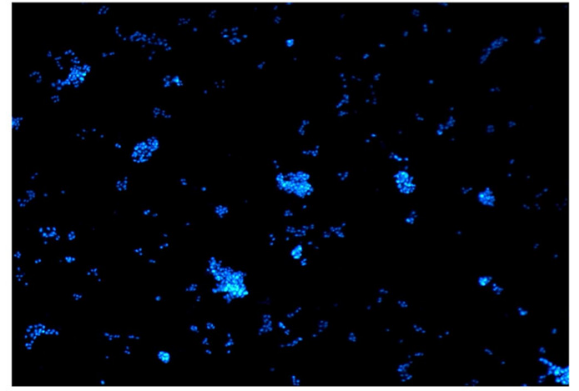

Nanocomposite treated cells

7 - AAD staining (10X)

C

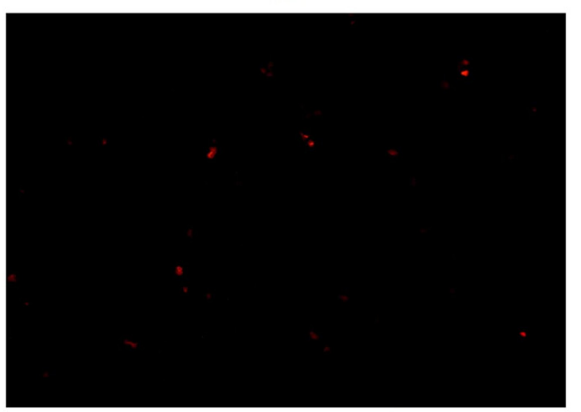

Nanocomposite treated cells

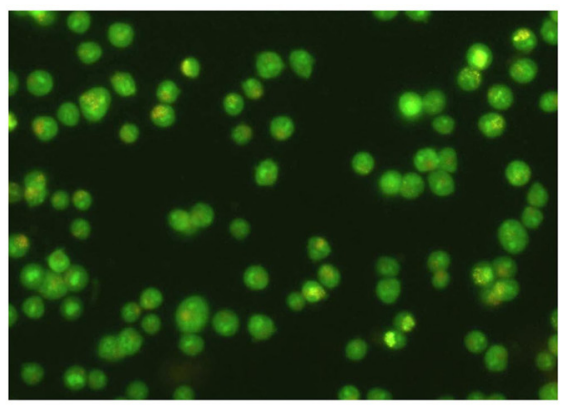

Control

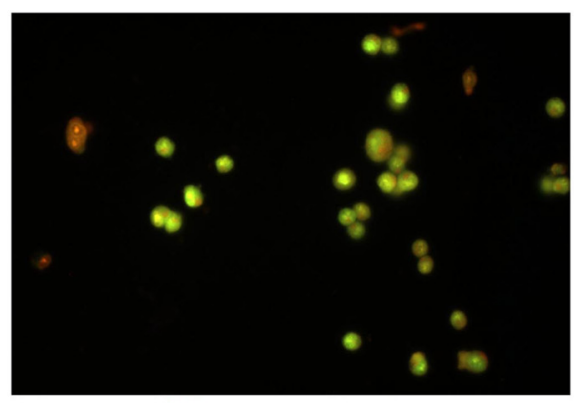

Nanocomposite treated cells

Figure 5 Apoptosis studies: I-car- $\gamma-\mathrm{Fe}_{2} \mathrm{O}_{3}$ nanocomposite led to apoptotic characteristics in $\mathrm{HCT} 116$ cells; (A) Control-Hoechst 33342 staining (10X), (B) Nanocomposite treated cells-Hoechst 33342 staining (10X), (C) Nanocomposite treated cells-7-AAD staining (10X), (D) Control-AO/EB staining (20X) and (E) Nanocomposite treated cells- AO/EB staining (20X).

chemotherapeutic regimen, A20-targeting agents (inducers and inhibitors) for each tumor hold great promise and could be a novel area for research.

Altogether, results confirm that the exposure of HCT116 cells to $\mathrm{l}$-car- $\gamma-\mathrm{Fe}_{2} \mathrm{O}_{3}$ nanocomposite resulted in apoptotic cell death, nuclear fragmentation, apoptosome formation, and upregulation of $\mathrm{Bcl}-2, \mathrm{Bcl}-\mathrm{xL}$ and caspase3 and downregulation of XIAP. It could be speculated that cell death in the nanocomposite treated cells could be due to the mitochondrial ROS and activation of death receptor signaling pathway.

\section{Methods}

Preparation of I-car- $\mathrm{\gamma}-\mathrm{Fe}_{2} \mathrm{O}_{3}$ nanocomposite

Maghemite nanoparticles were prepared as described by Russo et al. [60]. These were synthesized by the reduction 

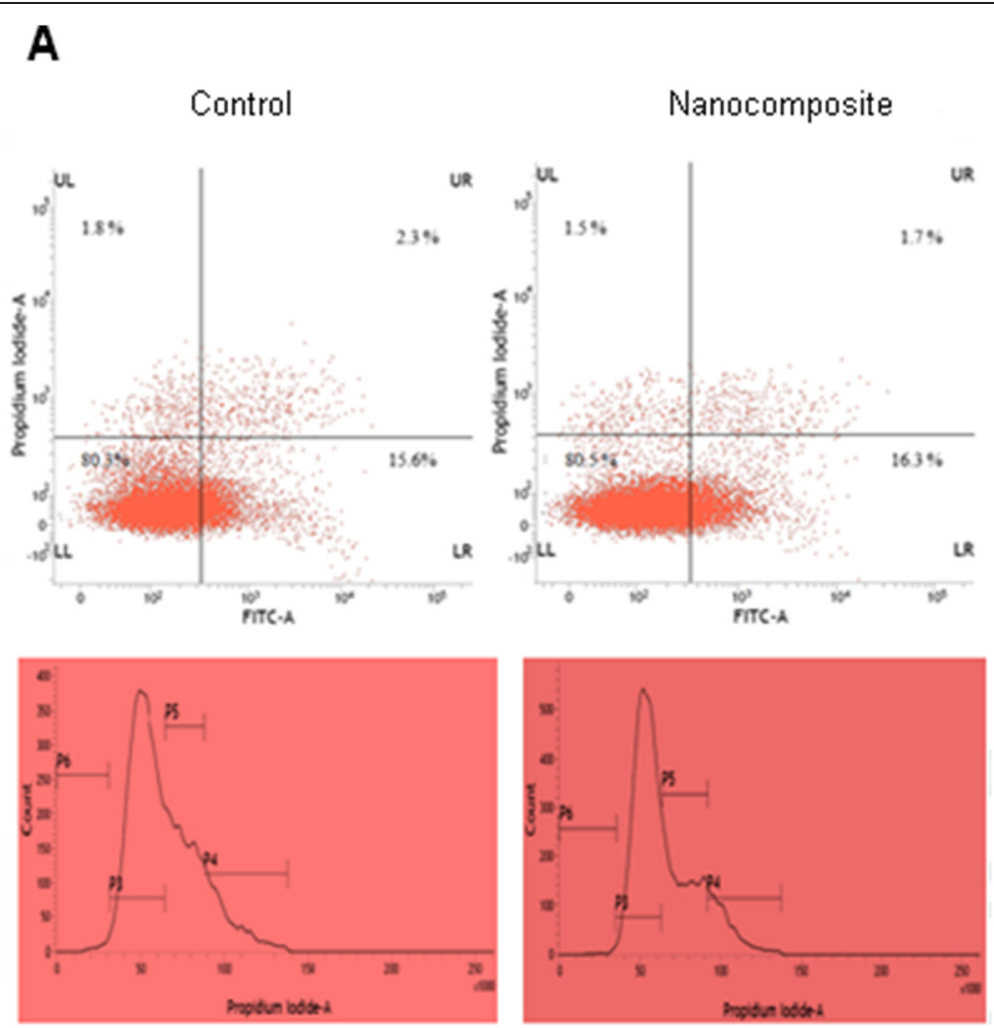

B

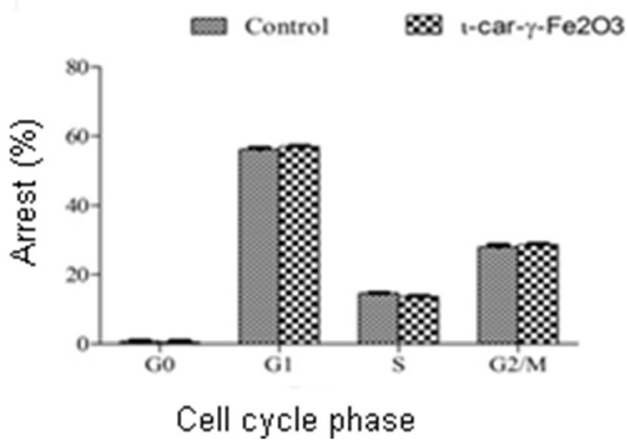

Figure 6 Apoptosis studies: (A) Quantification of apoptosis by the annexin-V/PI double staining assay using flow cytometry; LL (low left), LR (low right), UR (upper right), and UL (upper left) denote viable (live), early apoptotic, late apoptotic and necrotic cells, respectively. (B) The cell cycle analysis performed by flow cytometry showing percentage of arrest in different phases of cell cycle (P3-G1, P4-G2/M, P5-S and P6-G0 phases).

of ferric chloride $\left(\mathrm{FeCl}_{3} \cdot 6 \mathrm{H}_{2} \mathrm{O}\right)(37 \mathrm{mM})$ using ammoniacal solution (3.5\%) of sodium borohydride $\left(\mathrm{NaBH}_{4}\right)(53 \mathrm{mM})$. The mixture was heated at $100^{\circ} \mathrm{C}$ for $2 \mathrm{~h}$ and kept for overnight aging at room temperature. The aged black product was separated by neodymium magnets (N35, $263-287 \mathrm{KJ} / \mathrm{m}^{3} \mathrm{BH}$, and $1170-1210 \mathrm{~mJ}$ flex density by power magnet). The product was then washed several times with milli-Q water and treated at $400^{\circ} \mathrm{C}$ for $2 \mathrm{~h}$.
Reddish brown particles obtained were dispersed in 3.51 of milli-Q by ultrasonication for $10 \mathrm{~h}$. This gave a colloidal nanoparticle suspension with good stability.

A known weight $(7 \mathrm{mg})$ of $\mathrm{l}-$ car was dissolved in $10 \mathrm{ml}$ of Milli-Q water at $40^{\circ} \mathrm{C}$ for $15 \mathrm{~min}$, and $5 \mathrm{ml}$ of $\gamma$ $\mathrm{Fe}_{2} \mathrm{O}_{3}$ nanoparticle suspension $(4 \mu \mathrm{g} / \mathrm{ml})$ was added to this drop by drop, under mild stirring. After uniform dispersion by stirring and then sonication for 15 - 


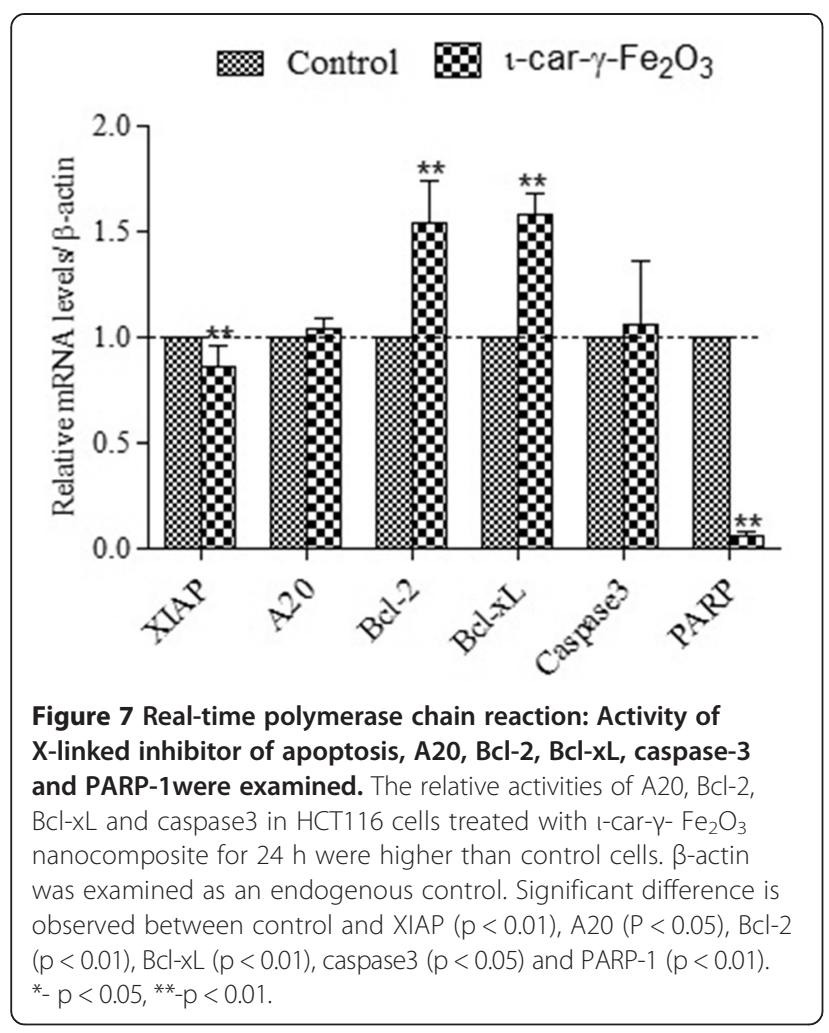

$30 \mathrm{~min}$, the suspension was lyophilized and stored at $4^{\circ} \mathrm{C}$ for further study.

\section{Characterization of I-car- $-\mathrm{-}-\mathrm{Fe}_{2} \mathrm{O}_{3}$ nanocomposite}

Size and surface charge of $1-\mathrm{car}$ and $\mathrm{t}-\mathrm{car}-\gamma-\mathrm{Fe}_{2} \mathrm{O}_{3}$ nanocomposite were estimated using Microtrac Particle Analyzer (Zetatrac, India). Surface morphology of the lyophilized products was analyzed using scanning electron microscope (FEI Quanta FEG 200-High Resolution Scanning Electron Microscope). UV spectra of $\mathrm{t}$-car and $\mathrm{t}$-car- $\gamma$ $\mathrm{Fe}_{2} \mathrm{O}_{3}$ nanocomposites $(1 \mathrm{mg} / \mathrm{ml})$ were obtained using UV/Visible spectrometer (UV/Vis Spectrophotometer, V550, Jasco Corporation, India; Spectra Manager ver.1.53.01, Jasco). FTIR spectra were recorded using a $\mathrm{KBr}$ pellet in FTIR spectrometer (Perkin Elmer, USA). The percentage transmittance $(\% \mathrm{~T})$ was recorded in the spectral region of $400-4500 \mathrm{~cm}^{-1}$ with 20 scan per sample. Powder X-ray diffraction patterns of $\mathrm{t}-\mathrm{car}$ and nanocomposite were recorded using CuK $\alpha$ radiation $(\lambda=0.1541 \mathrm{~nm})$ with Bruker D8 X-ray diffractometer.

\section{Anticancer activity of $\mathrm{t}-\mathrm{car}-\mathrm{\gamma}-\mathrm{Fe}_{2} \mathrm{O}_{3}$ nanocomposite}

Human embryonic kidney cell lines (HEK293) and rat myoblast cell lines (L6) were maintained in DMEM and human colon cancer cell line (HCT116) was maintained in RPMI1640, containing 10\% FBS and 5\% antibiotic in a humidified atmosphere of $5 \% \mathrm{CO}_{2}$, at $37^{\circ} \mathrm{C}$. The cytotoxic activity of $\mathrm{t}-\mathrm{car}, \gamma-\mathrm{Fe}_{2} \mathrm{O}_{3}$ and $\mathrm{t}-\mathrm{car}-\gamma-\mathrm{Fe}_{2} \mathrm{O}_{3}$ nanocomposite were evaluated against these cell lines using 3-[4, 5dimethythiazol-2-yl]-3, 5-diphenyltetrazolium bromide dye (MTT) [40]. $1 \times 10^{5}$ cells/ ml were seeded in $700 \mu \mathrm{L}$ of media in the wells of a 24-well microplate and incubated for $24 \mathrm{~h}$. Various concentrations of $\mathrm{t}$-car $(0,100$, $200,400,600,800$ and $1000 \mu \mathrm{g} / \mathrm{ml}), \gamma-\mathrm{Fe}_{2} \mathrm{O}_{3}(0,2.5,5,10$, 30,50 and $100 \mu \mathrm{g} / \mathrm{ml}$ ) and $\mathrm{l}-\mathrm{car}-\gamma-\mathrm{Fe}_{2} \mathrm{O}_{3}$ nanocomposite $(0,25,50,100,200,400,500 \mu \mathrm{g} / \mathrm{ml}$ in DMEM and RPMI 1640 , respectively at a $\mathrm{pH}$ of 7.4) were added and incubated for $24 \mathrm{~h} .70 \mu \mathrm{l} /$ well $(7.5 \mathrm{mg} / \mathrm{ml})$ of MTT in phosphate buffer saline (PBS) is added to each well and again incubated for $4 \mathrm{~h}$. The medium was removed and $700 \mu \mathrm{l} /$ well of dimethyl sulfoxide (DMSO) was added to dissolve the formazan. Cell viabilities were determined by measuring the absorbance at $570 \mathrm{~nm}$ using a Microplate reader (Enspire, Multimode plate reader, Perkin Elmer, Singapore). Each experiment was repeated thrice. The cell viability (\%) was calculated according to the following equation:

$$
\begin{aligned}
& \text { Cell viability }(\%)=\left(\text { OD570 }_{\text {sample }} /\right. \text { OD570 } \\
& \times 100
\end{aligned}
$$

Where, OD570 $0_{\text {sample }}$ and OD570 surements from the treated and untreated wells, respectively.

\section{Apoptosis studies}

For analysing the morphological changes due to apoptosis, cells were seeded at $3 \times 10^{5} \mathrm{cells} / \mathrm{ml}$ into the wells of a 6-well plate and cultured for $24 \mathrm{~h}$. Then they were treated with $500 \mu \mathrm{g} / \mathrm{ml}$ of I-car- $\gamma-\mathrm{Fe}_{2} \mathrm{O}_{3}$ nanocomposite, washed with PBS and stained with $10 \mu \mathrm{g} / \mathrm{ml}$ of Hoechst 33342 for $30 \mathrm{~min}$ at $37^{\circ} \mathrm{C}$. The cells were observed using an inverted fluorescent microscope (Leica Microsystems, Germany). The cells were fixed with cold $2 \%$ of paraformaldehyde (PFA) for $20 \mathrm{~min}$, washed with cold PBS and stained with 7-aminoactinomycin (7-AAD) for $20 \mathrm{~min}$. They were then observed using an inverted fluorescent microscope (Leica Microsystems, Germany) and photographed. To detect the nuclear damage or chromatin condensation, treated and untreated cells $\left(1 \times 10^{6}\right.$ cells $)$ were harvested using trypsin, washed and mixed with $100 \mu \mathrm{l}$ of PBS. $10 \mu \mathrm{l}$ of cells were double-stained using acridine orange (AO) and ethidium bromide (EB) $(5 \mu \mathrm{l}$ of $50 \mu \mathrm{g} / \mathrm{ml})$. They were then observed and photographed using an inverted fluorescent microscope (Leica Microsystems, Germany). Acridine orange is taken up by both viable and nonviable cells and they emit green fluorescence if intercalated into double-stranded nucleic acid (DNA) or red fluorescence if bound to single stranded nucleic acid (RNA). Ethidium bromide is taken up only by nonviable cells and so emits red fluorescence 
by intercalation into DNA. Based on the fluorescence emission and the morphological aspect of chromatin condensation in the stained nuclei, cells are classified as viable cells (uniform bright green nuclei with an organized structure), apoptotic cells (have intact membrane but have started to undergo DNA cleavage, so have green nuclei but perinuclear chromatin condensation is visible as bright green patches or fragments), late apoptotic cells (orange to red nuclei with condensed or fragmented chromatin) and necrotic cells (uniformly orange to red nuclei with a condensed structure). The study was done in triplicates. Percentage of apoptotic and necrotic cells were calculated using the following formulae,

$$
\begin{aligned}
\% \text { Apoptotic cells }= & (\mathrm{VA}+\mathrm{NVA}) /(\mathrm{VN}+\mathrm{VA} \\
& +\mathrm{NVN}+\mathrm{NVA}) \times 100 \\
\% \text { Necrotic cells }= & (\mathrm{NVN}) / \mathrm{VN}+\mathrm{VA}+\mathrm{NVN} \\
+ & \mathrm{NVA} \times 100
\end{aligned}
$$

Where,

$\mathrm{VN}=$ viable cells with normal nuclei (bright green chromatin with organized structure),

$\mathrm{VA}=$ viable cells with apoptotic nuclei (bright green chromatin which is highly condensed or fragmented) $\mathrm{NVN}=$ nonviable cells with normal nuclei (bright orange chromatin with organized structure), NVA = nonviable cells with apoptotic nuclei (bright orange chromatin which is highly condensed or fragmented).

The morphology of apoptotic cells was determined with the help of an annexin V-FITC and PI doublestaining technique [41]. HCT116 cells were seeded onto 6-well plates $\left(5 \times 10^{3}\right.$ cells/well $)$ and cultured for $24 \mathrm{~h}$. After treatment with or without $\mathrm{l}-\mathrm{Car}-\gamma-\mathrm{Fe}_{2} \mathrm{O}_{3}$ for $24 \mathrm{~h}$, they were stained with the annexin V-FITC labeling solution and $5 \mu \mathrm{l}$ of PI $(50 \mu \mathrm{g} / \mathrm{ml})$. The plates were incubated for $15 \mathrm{~min}$ in the dark, and then images of the cells were acquired using BD FACSVerse ${ }^{\text {tax }}$ flow cytometer. The nucleus of the cells with apoptotic morphology (condensation/fragmentation) or annexin $\mathrm{V}$-positive cells was analyzed using the BD FACSuite ${ }^{\mathrm{su}}$ software (BD Biosciences, Germany). For each analysis, 3000 cells were recorded.

Distribution of the cells in various phases in the cycle was determined using a flow cytometre [41]. After treatment with or without $1-\mathrm{car}-\gamma-\mathrm{Fe}_{2} \mathrm{O}_{3}$, the cells were harvested using trypsin, washed with cold PBS and incubated with $10 \mu \mathrm{g} / \mathrm{ml}$ of RNase A for $30 \mathrm{~min}$ at room temperature. PI $(5 \mu \mathrm{l}$ of $5 \mu \mathrm{g} / \mathrm{ml})$ was added to the cell suspension and they were incubated for $10 \mathrm{~min}$ in the dark. The DNA content was analyzed by flow cytometre (BD FACSVerse $^{\mathrm{mm}}$ flow cytometer, BD FACSuite ${ }^{\mathrm{Tm}}$ software,
BD Biosciences, Germany). The proportion of cells in G1, $\mathrm{S}$ and G2/ M phases were determined. 10000 cells were recorded during each reading.

ROS plays a key role in the oxidative stress and its imbalance causes cellular damage. To quantify ROS, cells were incubated with $\mathrm{t}-\mathrm{car}-\gamma-\mathrm{Fe}_{2} \mathrm{O}_{3}$ and labeled with $2 \mu \mathrm{l}$ of $20 \mathrm{mM}$ stock solution of 2', 7'-dichlorofluorescin diacetate (DCFH-DA) at $37^{\circ} \mathrm{C}$ for $30 \mathrm{~min}$. The cellular fluorescence intensity was measured after washing the cells with PBS at an excitation and emission wavelengths of 485 and $530 \mathrm{~nm}$, respectively, using a Microplate reader (Enspire, Multimode plate reader, Perkin Elmer, Singapore). DCFH-DA enters the cell where it reacts with ROS to form the highly fluorescent dichlorofluorescein (DCF) [61].

\section{Real-time polymerase chain reaction}

Cells were harvested after $24 \mathrm{~h}$ of treatment with PBS and $500 \mu \mathrm{g} / \mathrm{ml}$ of $\mathrm{t}-\mathrm{car}-\gamma-\mathrm{Fe}_{2} \mathrm{O}_{3}$. Total-RNA was extracted using the RNAiso Plus (Total RNA extraction reagent, Takara Bio Inc., Japan) [62]. The quality of RNA was evaluated by measuring the absorbance (Nanodrop 2000 Spectrophotometer, Thermoscientific, USA) at 260 and $280 \mathrm{~nm}$ which indicates its concentration and purity. The High Capacity cDNA Reverse Transcription Kits Protocol (Life Technologies, India) was used to prepare the cDNA according to the manufacturer's instructions. All the samples were stored at $-20^{\circ} \mathrm{C}$. Quantitative PCR was conducted in $20 \mu \mathrm{l}$ reactions containing KAPA SYBR $^{\bullet}$ FAST qPCR kit (KAPA Biosystems, Wilmington, Massachusetts) using the Mastercycler ep realplex ${ }^{4}$ PCR system (Eppendorf, Australia). The primers are shown in Table 3. Reaction mixtures were incubated for an initial denaturation at $95^{\circ} \mathrm{C}$ for 3 min followed by 40 cycles of $95^{\circ} \mathrm{C}$ for $3 \mathrm{sec}, 56^{\circ} \mathrm{C}$ for $15 \mathrm{sec}$ and $72^{\circ} \mathrm{C}$ for $15 \mathrm{sec}$. For each sample, the expression level of each mRNA was quantified as the cycle threshold difference $\left(\Delta \Delta \mathrm{C}_{\mathrm{t}}\right)$ with respect to $\beta$-actin as internal housekeeping gene. Real time PCR data were analyzed using the $2^{-\Delta \Delta C t}$ relative quantification method using the given formulae. All the reactions were performed in triplicate.

Table 3 Primers for real-time PCR

\begin{tabular}{lll}
\hline & Forward: & Reverse: \\
\hline B-actin & 5'-CTCACCATGGATGATGATATCGC & 5'-AGGAATCCTTCTGACCCATGC \\
XIAP & 5'-GCGCGAAAAGGTGGACAAGT & 5'- CTGCTCGTGCCAGTGTTGAT \\
A20 & 5'-AGTCTGCAGTCTTCGTGGC & 5'-AGTCCTGGTCAAGGCAGGAG \\
BCl-2 & 5'-TCCTGGCTGTCTCTGAAGACT & 5'-AGCCTGCAGCTTTGTTCAT \\
BCl-xL & 5'-ACTCTTCCGGGATGGGGTAA & 5'-AATGAGGTGCAAAGTCCCCC \\
PARP-1 & 5'-CTACTCGGTCCAAGATCGCC & 5'-TGAAAAAGCCCTAAAGGCTCA \\
\hline
\end{tabular}


$\Delta \Delta \mathrm{C}_{\mathrm{t}}=\left(\mathrm{C}_{\mathrm{t}}(\right.$ target, untreated $)-\mathrm{C}_{\mathrm{t}}($ ref, untreated $\left.)\right)$ $-\left(\mathrm{C}_{\mathrm{t}}(\right.$ target, treated $)-\mathrm{C}_{\mathrm{t}}($ ref, treated $\left.)\right)$

where

$C_{t}$ (target, untreated $)=C_{t}$ value of gene of interest in untreated sample

$C_{t}$ (ref, untreated $)=C_{t}$ value of control gene in untreated sample

$C_{t}$ (target, treated $)=C_{t}$ value of gene of interest in treated sample

$\mathrm{C}_{\mathrm{t}}($ ref, treated $)=\mathrm{C}_{\mathrm{t}}$ value of control gene in treated sample

\section{Western blot analysis}

Untreated HCT 116 (control) and cells treated with $500 \mu \mathrm{g} / \mathrm{ml}$ of $\mathrm{t}-\mathrm{car}-\gamma-\mathrm{Fe}_{2} \mathrm{O}_{3}$ nanocomposite for $24 \mathrm{~h}$, were lysed and whole cell lysates were extracted with RIPA (Radio-Immunoprecipitation Assay) lysis buffer and protein concentrations were measured using Nanodrop 2000 Spectrophotometer (Thermoscientific, USA). Samples containing equal concentrations of protein were separated by $10 \%$ SDS-PAGE (Bio-Rad Mini Protean Tetra Cell, India) and transferred to nitrocellulose membranes and blot device (Kiran X-ray Cassette, Kiran Medical Systems Ltd, India). The nitrocellulose sheet was incubated for $1 \mathrm{~h}$ with $5 \%$ milk (v/v). Pre-stained and un-stained broad range protein ladder (Puregene, Genetix Biotech Asia Pvt. Ltd., India) was used to distinguish MW of PARP and its cleavage products, noting that the MW of PARP was $116 \mathrm{kD}$, the apoptotic degradation product was $89 \mathrm{kD}$, and the necrotic products were $50 \mathrm{kD}$ [54]. The membranes were blocked with 5\% skimmed milk in phosphate saline buffer with Tween for $1 \mathrm{~h}$ at room temperature and maintained overnight at $4^{\circ} \mathrm{C}$ with PARP antibody (rabbit) prepared in skimmed milk (Cell Signaling Technology Inc., India). Membranes were then incubated with anti-rabbit horseradish peroxidaseconjugated secondary antibodies (Cell Signaling Technology Inc., India) at room temperature for $1 \mathrm{~h} 30 \mathrm{~min}$. Antibody-bound proteins were detected using enhanced chemiluminescence (ECL).

\section{Statistical analysis}

Groups of data were compared with Analysis of variance (ANOVA) using SPSS software (Chicago, IL, USA). A $\mathrm{p}$ value less than 0.05 was considered to be statistically significant.

\section{Conclusions}

This novel, biocompatible and biodegradable hybrid nano t-CGN- $\gamma-\mathrm{Fe}_{2} \mathrm{O}_{3}$ composite has been successfully prepared and characterized by various analytical techniques such as UV-spectroscope, HR-SEM, DLS, FTIR and Powder XRD. The results confirm the integration of maghemite nanoparticles to the sulphate groups of carrageenan. They have properties that can make them attractive and lucrative in biomedical applications. Tuning the surface properties of this nanocomposite by changing the concentration ratio of $\mathrm{t}-\mathrm{car}$ and $\gamma-\mathrm{Fe}_{2} \mathrm{O}_{3}$ can make them more dynamic in targeting cancer cells. Initiating the inhibition of growth in cancer cells without being cytotoxic to normal cell lines makes it a promising nanovector in drug delivery. The nanocomposite induces alterations in the cancer cells that are related to the apoptosis process through ROS-mediated mitochondrial pathway, by increasing ROS production and inducing mitochondrial oxidative damage, combined with upregulation of

A

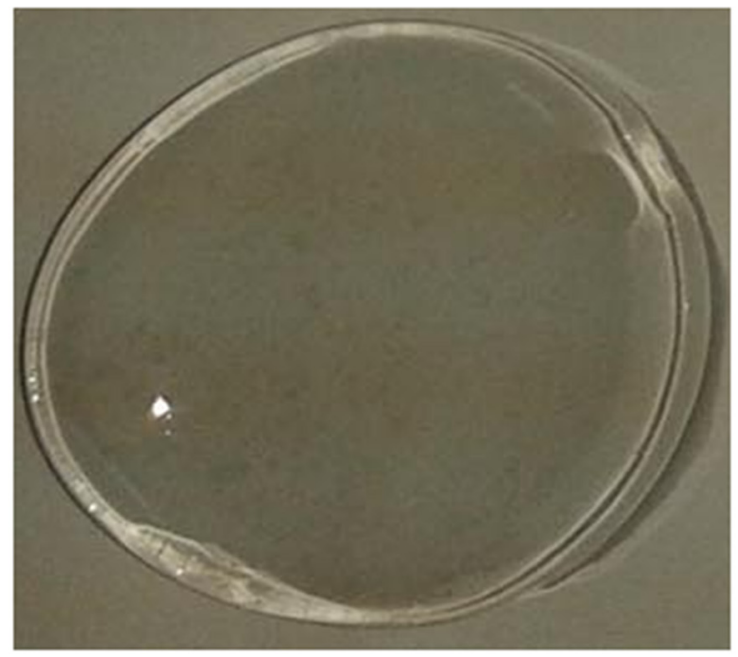

B

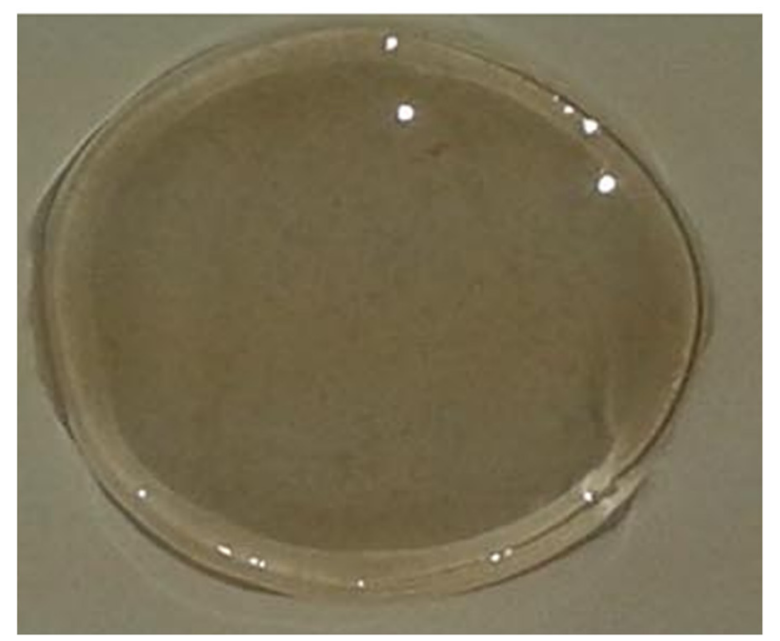

Figure 8 Gel Formation: Gels from (A) I-car with cations and (B) l-car with $\mathrm{\gamma}-\mathrm{Fe}_{2} \mathrm{O}_{3}$. 
caspase 3 and activation of death receptor signaling pathway. This is also accompanied by upregulation of Bcl-2 and $\mathrm{Bcl}-\mathrm{xL}$ indicating the damage of mitochondrial wall and probable production of pro-apoptotic proteins. Hence the I-car- $\gamma-\mathrm{Fe}_{2} \mathrm{O}_{3}$ nanocomposite has potential as an efficient chemotherapeutic agent, since targeting of chemotherapeutic agents is related to its capacity to induce apoptosis.

Our studies on gelation (data not shown, except Figure 8) showed that $1-\mathrm{CGN}$ with $\gamma-\mathrm{Fe}_{2} \mathrm{O}_{3}$ nanoparticles did not require any addition of cations, as $\gamma-\mathrm{Fe}_{2} \mathrm{O}_{3}$ nanoparticles themselves served as cations in neutralizing the charges and in promoting gelation. Gel forming ability of the nanocomposite can be exploited in targeted drug delivery and cancer hyperthermia. Surface charge, gel forming ability and the magnetic properties of our I-CGN- $\gamma-\mathrm{Fe}_{2} \mathrm{O}_{3}$ composite can be tuned to fit into appropriate applications by changing the nanoparticle concentration. Research to explore their significance in chemotherapy, controlled drug delivery and hyperthermia are to be continued.

\section{Additional files}

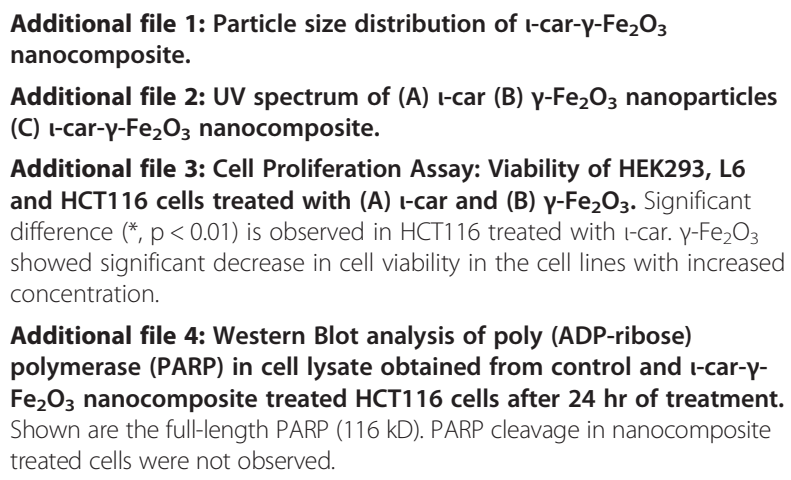

\section{Abbreviations}

MRI: Magnetic Resonance Imaging; $\gamma$ - $\mathrm{Fe}_{2} \mathrm{O}_{3}$ : Gamma maghemite; I -car: lota -Carrageenan; G4S: D-galactose-4-sulphate; DA2S: 3, 6-anhydro-D-galactose2-sulfate; HEK293: Human embryonic kidney cell lines; L6: Rat myoblast cell lines; HCT116: Human colon cancer cell line; DMEM: Dulbecco's modified Eagle's medium; RPMI: Roswell Park Memorial Institute medium; FBS: Fetal bovine serum; MTT: 3-(4, 5-dimethylthiazol-2-yl)-2, 5-diphenyltetrazolium bromide; 7-AAD: 7-Aminoactinomycin.

\section{Competing interests}

The authors declare that they have no competing interests.

\section{Authors' contributions}

MD supervised our studies, analyzed and finalized the manuscript, DVR contributed in preparation and characterization of the nanocomposite, MR contributed in exploring the biocompatibility and anticancer efficacy of the composite. All the authors read and approved the final manuscript.

\section{Acknowledgements}

MR acknowledges Women Scientist Scheme-A (SR/WOS-A/LS-459/2011), Department of Science and Technology, Government of India and VD acknowledges Women postdoctoral scheme, IITM for the financial support. MR and VD acknowledge Dr. Suresh Kumar Rayala, Mr. Anuj and Mr. Rakesh
Nankar for their support. The authors also acknowledge Sophisticated Analytical Instrument Facility at Indian Institute of Technology, Madras for the analytical facility provided.

Received: 13 October 2014 Accepted: 17 February 2015

Published online: 03 March 2015

\section{References}

1. Iconaru SL, Prodan AM, Motelica-Heino M, Sizaret S, Predoi D. Synthesis and characterization of polysaccharide-maghemite composite nanoparticles and their antibacterial properties. Nanoscale Res Lett. 2012;7:1-8.

2. Niemirowicz K, Markiewicz KH, Wilczewska AZ, Car H. Magnetic nanoparticles as new diagnostic tools in medicine. Adv Med Sci. 2012;57:196-207

3. Lemarchand C, Gref R, Couvreur P. Polysaccharide-decorated nanoparticles. Eur J Pharm Biopharm. 2004;58:327-41.

4. Muthiah M, Park IK, Cho CS. Surface modification of iron oxide nanoparticles by biocompatible polymers for tissue imaging and targeting. Biotechnol Adv. 2013:31:1224-36.

5. Batalha IL, Hussain A, Roque ACA. Gum Arabic coated magnetic nanoparticles with affinity ligands specific for antibodies. J Mol Recognit. 2010:23:462-71.

6. Pourjavadi A, Hosseini SH, Seidi F, Soleyman R. Magnetic removal of crystal violet from aqueous solutions using polysaccharide-based magnetic nanocomposite hydrogels. Polym Int. 2013;62:1038-44.

7. Zheng Y, Monty J, Linhardt RJ. Polysaccharide-based nanocomposites and their applications. Carbohydr Res. 2014. DOl: 10.1016/j.carres.2014.07.016.

8. Saha S, Pal A, Kundu S, Basu S, Pal T. Photochemical green synthesis of calcium-alginate-stabilized $\mathrm{Ag}$ and Au nanoparticles and their catalytic application to 4-nitrophenol reduction. Langmuir. 2009;26:2885-93.

9. Kaushik A, Khan R, Solanki PR, Pandey P, Alam J, Ahmad S, et al. Iron oxide nanoparticles-chitosan composite based glucose biosensor. Biosens Bioelectron. 2008;24:676-83.

10. Shan L. FluidMAG Iron Nanoparticle-Labeled Mesenchymal Stem Cells for Tracking Cell Homing to Tumors. Molecular Imaging and Contrast Agent Database (MICAD) [Internet]. Bethesda (MD): National Center for Biotechnology Information (US); 2004-2013.

11. Su H, Liu Y, Wang D, Wu C, Xia C, Gong Q, et al. Amphiphilic starlike dextran wrapped superparamagnetic iron oxide nanoparticle clsuters as effective magnetic resonance imaging probes. Biomaterials. 2013;34:1193-203.

12. Ling-Yun Z, Jia-Yi L, Wei-Wei O, Dan-Ye L, Li L, Li-Ya L, et al. Magneticmediated hyperthermia for cancer treatment: Research progress and clinical trials. Chin Phys B. 2013;22:108104.

13. Zamora-Mora V, Fernández-Gutiérrez M, Román JS, Goya G, Hernández R, Mijangos C. Magnetic core-shell chitosan nanoparticles: Rheological characterization and hyperthermia application. Carbohydr Polym. 2014;102:691-8.

14. Silva AKA, Letourneur D, Chauvierre C. Polysaccharide Nanosystems for Future Progress in Cardiovascular Pathologies. Theranostics. 2014;4:579.

15. Zhu Y, Lin Y, Zhu YZ, Lu J, Maguire JA, Hosmane NS. Boron drug delivery via encapsulated magnetic nanocomposites: a new approach for BNCT in cancer treatment. J Nanomater. 2010;24. DOI:10.1155/2010/409320.

16. Lim EK, Sajomsang W, Choi Y, Jang E, Lee H, Kang B, et al. Chitosan-based intelligent theragnosis nanocomposites enable $\mathrm{pH}$-sensitive drug release with MR-guided imaging for cancer therapy. Nanoscale Res Lett. 2013:8:1-12.

17. Silva TH, Alves A, Ferreira BM, Oliveira JM, Reys LL, Ferreira RJF, et al. Materials of marine origin: a review on polymers and ceramics of biomedical interest. Int Mat Rev. 2012;57:276-306.

18. Prajapati VD, Maheriya PM, Jani GK, Solanki HK. Carrageenan: a natural seaweed polysaccharide and its applications. Carbohydr Polym. 2014;105:97-112

19. Li L, Ni R, Shao Y, Mao S. Carrageenan and its applications in drug delivery. Carbohydr Polym. 2014;103:1-11.

20. Khotimchenko YS, Khozhaenko EV, Khotimchenko MY, Kolenchenko EA, Kovalev W. Carrageenans as a new source of drugs with metal binding properties. MarDrugs. 2010;8:1106-21.

21. Raveendran S, Yoshida Y, Maekawa T, Kumar DS. Pharmaceutically versatile sulfated polysaccharide based bionano platforms. Nanomedicine. 2013;9:605-26

22. Carneiro MLB, Peixoto R, Joanitti GA, Oliveira R, Telles L, Miranda-Vilela AL, et al. Antitumor effect and toxicity of free rhodium (II) citrate and rhodium 
(II) citrate-loaded maghemite nanoparticles in mice bearing breast cancer. J Nanobiotechnol. 2013;11:4.

23. Jin $Z$, Han $Y X$, Han XR. Degraded iota-carrageenan can induce apoptosis in human osteosarcoma cells via the Wnt/ $\beta$-catenin signaling pathway. Nutr Cancer. 2013;65:126-31.

24. Gu YS, Regnier L, McClements DJ. Influence of environmental stresses on stability of oil-in-water emulsions containing droplets stabilized by B-lactoglobulin-1-carrageenan membranes. J Colloid linterface Sci. 2005;286:551-8,

25. Lemarchand C, Gref R, Passirani C, Garcion E, Petri B, Müller R, et al. Influence of polysaccharide coating on the interactions of nanoparticles with biological systems. Biomaterials. 2006;27:108-18

26. Grenha A, Gomes ME, Rodrigues M, Santo VE, Mano JF, Neves NM, et al. Development of new chitosan/carrageenan nanoparticles for drug delivery applications. J Biomed Mater Res, Part A. 2010;92:1265-72.

27. Kong $\mathrm{H}$, Song J, Jang J. One-step fabrication of magnetic $\gamma$-Fe $2 \mathrm{O} 3 /$ polyrhodanine nanoparticles using in situ chemical oxidation polymerization and their antibacterial properties. Chem Commun. 2010;46:6735-7.

28. Sekkal M, Legrand PA. Spectroscopic investigation of the carrageenans and agar in the 1500-100 cm - 1 spectral range. Spectrochim Acta, Part A. 1993:49:209-21.

29. Distantina S, Wirratni W, Fahrurrozi M, Rochmadi R. Carrageenan properties extracted from Eucheuma cottonii, Indonesia. World Acad Sci, Eng Technol. 2011;78:738-42.

30. Briones AV, Sato T. Structural Studies on I-Carrageenan Derived Oligosaccharides and Its Application. Adv Chem Eng Sci. 2013;4:17.

31. Arias M, Pantojas VM, Perales $\mathrm{O}$, Otaño W. Synthesis and characterization of magnetic ZnFe2O4 / $\mathrm{Y}$-Fe2O3 electrospun fibers. J Magn Magn Mater. 2011;323:2109-14

32. Millane RP, Chandrasekaran R, Arnott S, Dea I. The molecular structure of kappa-carrageenan and comparison with iota-carrageenan. Carbohydr Res. 1988:182:1-17

33. Janaswamy S, Chandrasekaran R. Sodium I-Carrageenan: A Paradigm of Polymorphism and Pseudopolymorphism. Macromolecules. 2006;39:3345-9.

34. Ariffin SHZ, Wong WY, Abidin IZZ, Wahab RMA, Ariffin ZZ, Senafi S Cytotoxicity effect of degraded and undegraded kappa and iota carrageenan in human intestine and liver cell lines. BMC Complement Alternat Med. 2014:14:508.

35. Prodan AM, Ciobanu CS, Popa CL, Iconaru SL, Predoi D. Toxicity evaluation following intratracheal instillation of iron oxide in a silica matrix in rats. BioMed Res Int. 2014;Article ID 134260:13. doi:10.1155/2014/134260.

36. Rudzka K, Viota JL, Muñoz-Gamez JA, Carazo A, Ruiz-Extremera A, Delgado ÁV. Nanoengineering of doxorubicin delivery systems with functionalized maghemite nanoparticles. Colloids Surf, B. 2013;111:88-96.

37. Štarha P, Stavárek M, Tuček J, Trávníček Z. 4-Aminobenzoic Acid-Coated Maghemite Nanoparticles as Potential Anticancer Drug Magnetic Carriers: A Case Study on Highly Cytotoxic Cisplatin-Like Complexes Involving 7-Azaindoles. Molecules. 2014;19:1622-34.

38. Amaral C, Borges M, Melo S, da Silva ET, Correia-da-Silva G, Teixeira N. Apoptosis and autophagy in breast cancer cells following exemestane treatment. PLoS One. 2012;7:e42398.

39. Liegler TJ, Hyun W, Yen TS, Stites DP. Detection and quantification of live, apoptotic, and necrotic human peripheral lymphocytes by single-laser flow cytometry. Clin Diagn Lab Immunol. 1995;2:369-76.

40. Nandakumar V, Vettriselvi V, Doble M. Toxicity of high glycolic poly (DL-lactic-co-glycolic acid) stabilized ruthenium nanoparticles against human promyelocytic leukemia cells. RSC Adv. 2014;4:11438-43.

41. Zhang Z, Teruya K, Yoshida T, Eto H, Shirahata S. Fucoidan extract enhances the anti-cancer activity of chemotherapeutic agents in MDA-MB-231 and MCF-7 breast cancer cells. Mar Drugs. 2013;11:81-98.

42. Quan Z, Gu J, Dong P, Lu J, Wu X, Wu W, et al. Reactive oxygen speciesmediated endoplasmic reticulum stress and mitochondrial dysfunction contribute to cirsimaritin-induced apoptosis in human gallbladder carcinoma GBC-SD cells. Cancer Lett. 2010;295:252-9.

43. Giorgio M, Trinei M, Migliaccio E, Pelicci PG, Trinei M, Migliaccio E, et al. Hydrogen peroxide: a metabolic by-product or a common mediator of ageing signals? Nat Reviews Mol Cell Biol. 2007;8:722-8.

44. Klaunig JE, Kamendulis LM, Hocevar BA. Oxidative stress and oxidative damage in carcinogenesis. Toxicol Pathol. 2010;38:96-109.

45. Taylor WR, Stark GR. Regulation of the G2/M transition by p53. Oncogene. 2001;20:1803-15.
46. Li R, Waga S, Hannon GJ, Beach D, Stillman B. Differential effects by the p21 CDK inhibitor on PCNA-dependent DNA replication and repair. Nature. 1994;371:534-7.

47. Haneji K, Matsuda T, Tomita M, Kawakami H, Ohshiro K, Uchihara JN, et al. Fucoidan extracted from Cladosiphon okamuranus Tokida induces apoptosis of human T-cell leukemia virus type 1-infected T-cell lines and primary adult T-cell leukemia cells. Nutr Cancer. 2005;52:189-201.

48. da Silva CG, Minussi DC, Ferran C, Bredel M. A20 expressing tumors and anticancer drug resistance. Adv Exp Med Biol. 2014;809:65-81.

49. Eckelman BP, Salvesen GS, Scott FL. Human inhibitor of apoptosis proteins: why XIAP is the black sheep of the family. EMBO Rep. 2006;7:988-94.

50. Boucher C, Gobeil S, Samejima K, Earnshaw WC, Poirier GG. Identification and analysis of caspase substrates: proteolytic cleavage of poly(ADP-ribose) polymerase and DNA fragmentation factor 45. Methods Cell Biol. 2001;66:289-306.

51. Lee JM, Ledermann JA, Kohn EC. PARP Inhibitors for BRCA1/2 mutationassociated and BRCA-like malignancies. Ann Oncol. 2014;25:32-40.

52. Kaufmann SH, Desnoyers S, Ottaviano Y, Davidson NE, Poirier GG. Specific proteolytic cleavage of poly(ADP-ribose) polymerase: an early marker of chemotherapy-induced apoptosis. Cancer Res. 1993;53:3976-85.

53. Herceg Z, Wang ZQ. Failure of poly (ADP-ribose) polymerase cleavage by caspases leads to induction of necrosis and enhanced apoptosis. Mol Cell Biology. 1999;19:5124-33.

54. Shah GM, Shah RG, Poirier GG. Different cleavage pattern for poly (ADP-ribose) polymerase during necrosis and apoptosis in $\mathrm{HL}-60$ cells. Biochem Biophys Res Commun. 1996;229:838-44.

55. Bhattacharyya S, Borthakur A, Dudeja PK, Tobacman JK. Carrageenan induces cell cycle arrest in human intestinal epithelial cells in vitro. J Nutr. 2008;138:469-75.

56. Boulares AH, Yakovlev AG, Ivanova V, Stoica BA, Wang G, lyer S, et al. Role of poly (ADP-ribose) polymerase (PARP) cleavage in apoptosis Caspase 3-resistant PARP mutant increases rates of apoptosis in transfected cells. J Biol Chem. 1999:274:22932-40.

57. Kim EJ, Park SY, Lee JY, Park JH. Fucoidan present in brown algae induces apoptosis of human colon cancer cells. BMC Gastroenterol. 2010:10:96.

58. Leist M, Single B, Kunstle G, Volbracht C, Hentze H, Nicotera P. Apoptosis in the absence of poly-(ADP-ribose) polymerase. Biochem Biophys Res Commun. 1997;233:518-22.

59. Vercammen D, Beyaert R, Denecker G, Goossens V, Van Loo G, Declerca W, et al. Inhibition of caspases increases the sensitivity of $L 929$ cells to necrosis mediated by tumor necrosis factor. J Exp Med. 1998;187:1477-85.

60. Russo U, Nodari L, Vianello F, Magro M, Valle G. Patent No. 20,130,122,303. Washington, DC: U.S. Patent and Trademark Office; 2013.

61. Eruslanov E, Kusmartsev S. Identification of ROS using oxidized DCFDA and flow-cytometry. Methods Mol Biol. 2010;594:57-72.

62. Park HY, Kim GY, Moon SK, Kim WJ, Yoo YH, Choi YH. Fucoidan inhibits the proliferation of human urinary bladder cancer T24 cells by blocking cell cycle progression and inducing apoptosis. Molecules. 2014;19:5981-98.

\section{Submit your next manuscript to BioMed Central and take full advantage of:}

- Convenient online submission

- Thorough peer review

- No space constraints or color figure charges

- Immediate publication on acceptance

- Inclusion in PubMed, CAS, Scopus and Google Scholar

- Research which is freely available for redistribution 